\title{
THE EFFECT OF THE UNITED STATES OUT OF PARIS AGREEMENT OF 2015 ON THE NATIONAL SECURITY OF THE UNITED STATES
}

\author{
${ }^{1}$ Hazazi Ridho Subarkah, ${ }^{2}$ Yanyan M. Yani, ${ }^{3}$ Taufik Hidayat \\ ${ }^{1,2,3}$ Political Science, Universitas Padjajaran, Bandung, Indonesia \\ I'hazazi17001@mail.unpad.ac.id, ${ }^{2} y a n 2 m @$ hotmail.com, ${ }^{3}$ taufik_hidayat_hi@yahoo.com
}

\begin{abstract}
This research will discuss climate change, which causes national security threats to several countries. To tackle climate change, the United States ratified the Paris Agreement 2015, but in 2017 the United States left the agreement. The position of the United States is important because it is both an emitter and a cause of climate change. So that climate change influences the national security of the United States. This study was analyzed using the concept of safety and environmental safety. The idea of security used to analyze the threats caused by climate change to the United States national security threats, and the concept of environmental protection is to analyze the ecological crisis as a threat because it is no longer able to sustain human life. This research method with qualitative methods and data collection techniques through a literature study. The results of this study, based on the findings of climate change as a threat to the United States, can have an impact on health, food availability, requests, and coastal areas. It also disrupted military bases and operations in several international and domestic sectors.
\end{abstract}

Keywords: America, Threat, Environment

DOI: $10.33541 /$ sp.v20i2.1353

Sociae Polites : Majalah IImiah Sosial Politik

Faculty of Social and Political Science, Universitas Kristen Indonesia

ISSN 1410-3745 print/ ISSN 2620-4975 online

Volume 20, Number 2 (July - December 2019)

Pages 145-163 


\section{Introduction}

\subsection{Background}

Environmental degradation does not recognize national borders. Therefore ecological problems in a country can have direct or indirect impacts on many countries (Bakry 2017: 278). The result was a direct impact on neighboring Malaysia, Singapore, and Thailand expos to haze for months. The indirect implications can befall the whole world, considering that tropical forests in Indonesia are one of the "lungs" of the world. Regarding this matter, a country can no longer assume that environmental problems are only internal problems, but all countries must work together to create ecological security (Bakry 2017: 278).

Any amount of carbon gas emissions can have a meteorological influence and impact, which means not only an environmental problem but a global problem. The use of transportation that produces carbon emissions and factories contributes to pollution that spread throughout the world, which also triggers climate change through the greenhouse effect. Another problem is the use of Cloro Floro Carbon (CFC), which is local but can cause the ozone layer to thin out and even be hollow in Antarctica and Africa. The use of CFC, which is locally and feels small, actually causes an influence on the global environment (Attfield 2010: 21). The countries with the highest carbon emissions are China, the United States, the European Union, India, Russia, Japan, Germany, South Korea, Canada, and Indonesia (CNN Indonesia 2015).

The Intergovernmental Panel On Climate Change (IPCC) states that 95\% of the causes of climate change are human-based. Therefore it is essential for immediate progressive action, but studies conducted by the IPCC did not get a severe response, especially the largest emitter countries (WALHI 2015: 25). The World Meteorological Organization (WMO) report shows that carbon dioxide reached a record high with a CO2 concentration of 403.3 parts per million (ppm) in 2016, up from $400 \mathrm{pp}$, in 2015. That is indicated by industrialization activities that began in 1750, which supported by growth factors and the use of fossil fuels (CNN Indonesia 2017)

The United States has responded to climate change differently. During President Barack Obama's administration, the United States ratified the Paris Agreement 2015, which contained efforts to tackle climate change (Reuters 2016). The contradiction occurred after Donald John Trump replaced the United States. During the administration of Trump, the United States announced the withdrawal of the Paris climate agreement in 2015, which had been ratified by the previous government (BBC News 2017).

The exit of the United States has implications for the target of reducing global temperatures below 2 degrees celsius will be increasingly difficult. Because the United States is the second-largest emitter country globally and at that time promised to reduce emissions 26-28 percent below the 2005 emission level in 2025. The Climate Interactive team from MIT, in its analysis, stated without the participation of the United States, the global temperature would be 0.3 degrees higher end of the century. The U.S. contribution to total global emission reduction reached 21 percent (IESR 2017).

The departure of the United States from the 2015 Paris Agreement will affect its global and domestic security threats. Bearing in mind that environmental problems are joint problems, which must deal with together. Climate change as a national security threat stated by Synder: "In the context of the era of threats. Threats to security can 
come from other issues, such as environmental degradation, resource depletion, disease, forced migration, and organized transnational crime. Also, security can come from a balance of all instruments of foreign policy." he explained that security threats could come from anywhere, including environmental degradation (Winarno 2014: 5).

Threats to individuals and countries due to climate change occur in various sectors, ranging from drought and floods that cause crop failure or other disasters. Pollution can interfere with breathing, disease outbreaks, and decreased world food availability (Senthilingam 2016). Security threats from climate change will occur migration, the World Bank, in its report, states that the impact of climate change will force 140 million people in the world to move from their countries by 2050 . Based on a review of three developing regions in the world, Africa, sub-Saharan, South Asia, and American Latin. Residents who migrate due to climate change are called climate migrants. They are people who leave their territory due to water scarcity, crop failure, sea-level rise, and storms (Kompas International 2018).

The United States, as one of the global emitters with the exit from the Paris Agreement 2015, has implications from the threat of climate change on global security. Previous research from Aron Saad (2018), who wrote a journal titled "Pathways of Harm: The Consequences of Trump's Withdrawal from the Paris Climate Agreement." The study tries to explain the possible consequences of climate change handling on the release of the United States from the Paris Agreement, namely, first, the continued use of fossil fuels. Second, slowing efforts to tackle climate change. Third, there is resistance at the international level regarding the future of policies dealing with climate change. Fourth, funding for countries vulnerable to the effects of climate change will cancel (Saad 2018).

Other research of the Paris Agreement 2015 from the writings of Christopher J. Rhodes (2017) with the title "U.S. withdrawal from the COP21 Paris Climate Change Agreement and Its Possible Implication." The study tries to explain the exit of the United States from the Paris Agreement because Trump was elected President of the United States from the Republican party, which rejected the Clean Power Plan proposal submitted by Obama as the previous President of the United States. As for the consequences of the withdrawal of the United States followed by other countries, because with the postponement of efforts to deal with climate change by world countries, there will be global warming of more than 2 degrees Celsius. It also fears that the Paris Agreement 2015 will repeat with previous agreements that have terminated, such as the Marrakech Agreement stalled (Rhodes 2017).

Furthermore, research from Qimin Chai, et al. on the title "The gap report of global climate change mitigation, finance, and governance after the United States declared its withdrawal from the Paris Agreement." The study seeks to explain its evaluation of the three central deficits with the release of the United States of the Paris Agreement, namely in terms of mitigation, climate finance, and climate governance. In terms of reduction, it will be challenging to implement climate policies that can reduce 8.8-13.4\% of global emissions. The United States naturally gets a $40 \%$ burden on global emissions, with the exit from the Paris Agreement, the E.U. receives a more substantial burden to $70 \%$. In terms of funding, the withdrawal of the United States from the Paris Agreement will worsen the existing climate funding mechanism. The United States influences global climate governance. During COP21 in Paris, America had an essential role in joint commitments with other developing countries, namely with 79 African 
countries and the Caribbean and South Pacific. The exit of the United States influences other countries to participate in dealing with climate change (Chai et.all, 2017).

Another study is from Zhang Hai-Bin, et.all (2017) with the title "The U.S. With the withdrawal from the Paris Agreement: Reasons, Impacts, and China's Response," this study describes the reasons for the United States leaving the Paris Agreement and the impact and response from China. One reason for the exit of the United States is Trump's proximity to its industrial entrepreneurs using fossil fuels, and this industry influences the politics of Trump and the Republican Party. Trump himself is skeptical of climate change. Trump rejects Obama's philosophy, which states that the ratification of the Paris agreement will strengthen the United States, and vice versa Trump said that confirmation would weaken the United States. The impact of the exit of the United States is that as a stable country, the leadership of the U.S., European Union, and China is essential to make other countries comply with the Paris agreement. China, which is at the same time as America, now lives alone in leading the control of climate change, but it is a challenge for China. As for the response that should be done by China, China must respond to the collective leadership call on global climate governance together in partnership with the European Union, India, Brazil, and South Africa (Zhang et al. 2017).

This study is different from previous research that this study discusses the exit of the United States from the Paris Agreement 2015 and its specific impact on the national security of the United States. Previous research only examines the effects of climate change caused globally. In contrast, in this study, the impact of climate change is a threat to the national security of the United States. Given the risks that come from various objects, and the state must protect its citizens from various external threats, in this case, from climate change issues that can affect national security. The expansion of the meaning of security in the contemporary era understands security not only from the military sector but from the degradation of environmental issues that can use as a threat to a country. President Obama, in his annual address to Congress, stated that climate change is the biggest threat to future generations (PBS News 2015).

It is interesting to study the impact of climate change on a country's national security threats. Previous research has not yet explained the danger of climate change to the national security of the United States. The impact of climate change is not only to one region but to the entire world, including the United States. Thus the United States coming out of the Paris Agreement 2015 undirectly threatens its national security. For this reason, this research will look at the forms of threats that result from climate change in the United States.

\subsection{Research Question}

Based on the background description, it is interesting to study about the United States as one of the global emitters out of the Paris Agreement 2015, with its release making climate change a global and domestic problem as well as a national security threat to the United States. It is a question for the author, "how does the influence of the United States get out of Paris Agreement 2015 on the national security of the United States?"

\subsection{Objectives and Purposes}


This study aims to determine the effect of the exit of the United States from the Paris Agreement 2015 on its national security. As is known, the United States contributes the second carbon emissions in the world, with the exit from the Paris Agreement 2015 has an impact on the environment and thus has implications for national security.

Theoretically, it expects to be able to contribute to the study of the science of International Relations, especially regarding environmental security that can influence the national security of the United States. Practically, it hopes that this will use as a reference for policymakers in analyzing environmental issues, that ecological safety is essential for maintaining internal security.

\section{Literature Review}

\subsection{National Security and Environmental Safety}

National security generally defines as the basic need to protect and safeguard the national interests of a nation and state by using political, economic, and military forces to face threats both at home and abroad. National security can also interpret as the need to preserve and maintain the existence of the state through economic, military, and political forces and the development of diplomacy (Darmono et.all, 2010: 9).

National security emerges along with the state's efforts to create security for everything in its territory. In simple terms, national security understood as a condition for the physical protection of the country from external threats, which in its development, national security can also get threats from its internal (Rachmat, 2015: 7).

According to Wolfers in the book, Perwita \& Yani (2017) defines security "Security, in any objective sense, measures the absence of threats to acquired values and in a subjective sense, the absence of fear that such values will tack." He explained that security is the absence of threats from various objects. Traditionally, the concept of security so far has only referred to the nature of risks that are military and focus on aspects of the state (Perwita \& Yani, 2017: 121). Scholars of International Relations argue that the concept of security dominant by the Realism community, which says the idea of security as a condition. That is free from military threats or the ability of a country to protect the nation-state from military attacks originating from its external environment (the absence of military threat or with the protection of the nation from external overthrow or invasion) (Perwita, 2008: 6).

The concept of security itself needs to know from various dimensions, and the following can be described differences in the approach of traditional and non-traditional security concepts based on proportion in the table:

Tabel 1. Difference between Traditional dan non-traditional Security Concept

\begin{tabular}{|c|c|c|}
\hline & Traditional & Non-Traditional \\
\hline (Origin of threats) & Rival State & $\begin{array}{c}\text { Non-states: domestic } \\
\text { dan transnasional }\end{array}$ \\
\hline
\end{tabular}




\begin{tabular}{|c|c|c|}
\hline (Nature of threats) & CA & $\begin{array}{c}\text { Non Military: } \\
\text { Economic, domestic } \\
\text { politic, environment, } \\
\text { terrorism, infectious } \\
\text { diseases, Narcotic }\end{array}$ \\
\hline (The response) & Military & $\begin{array}{c}\text { Non-military: } \\
\text { economic } \\
\text { liberalization, } \\
\text { democratization, } \\
\text { human rights }\end{array}$ \\
\hline (the responsibility for \\
providing security) & States & $\begin{array}{c}\text { States, International } \\
\text { Organizations, } \\
\text { Individual }\end{array}$ \\
\hline (Core Values) & $\begin{array}{c}\text { National } \\
\text { independence, } \\
\text { territorial integrity, } \\
\text { sovereignty }\end{array}$ & $\begin{array}{c}\text { Economic well-being } \\
\text { Human Rights } \\
\text { protection of the } \\
\text { environment. }\end{array}$ \\
\hline
\end{tabular}

Source: Perwita, 2008:14

Perwita sees that there are five dimensions, namely Pratama, the proportion of "The origin of threats" from the origin of the threat, traditional security is when the danger comes from an opposing country. That is when there is a cold war between states. Non-traditional security usually comes from primordial countries such as ethnicity, culture, and religion, which manifest in communal conflicts, non-state actors, namely from environmental conditions that are experiencing degradation. The second dimension, "the nature of threats," is the nature of threats, if the traditional character of the danger is the military capability or the capacity of a country. The non-traditional security nature of the risk can be in the form of economic, socio-cultural, environmental, and even other issues such as democracy and human rights.

The third dimension, namely "Changing response," traditional security that is looking at the response to the problems that were born answers that appear violent/military. When the answer is non-military liberalization, economics, democratization, or human rights, it is called non-traditional security. The fourth dimension, "Changing responsibility of security. The last dimension is the "core values of security," traditional safety seen from the party responsible if the state as well as nontraditional security that is responsible for the country, organization, international, individual. The last dimension is "core values of security." If the value of security regarding national independence, territory integrity, sovereignty is traditional security. Non-traditional security is when the values human rights, democracy, protection of the environment, and efforts to fight transnational crime, whether narcotics trade, money laundering, and terrorism (Perwita, 2008: 11-14).

The shift in the meaning of the concept of security makes the concept of environmental protection in this study used to see the threat from the environment on national security. Barry Buzan, in his book Winarno (2014), shares the concept of security not only in the military but also in political, economic, socio-cultural, and environmental protection. In particular, the protection of the environment he stated environmental security includes the maintenance of the local environment as a significant supporter of the human environment (Winarno, 2014: 16). 
The United Nations (U.N.) Security Council in 2007 released environmental degradation as a security issue. The negative impacts arising from climate change have the potential to affect regional and domestic instability when it coincides with ethnic, cultural, political, or economic issues. For example, territorial modifications caused by a rise in sea custody have the potential to afflict border disputes or sea zone divisions. The scientists gave their opinion on the assumption that land, water resources would gradually become more scarce in the coming years, this would then have the potential for conflict because of fighting over available resources (United Nations Security Council. 2007).

Perwita and Yani (2017) suggested that military security turned into nonmilitary. The issue of global environmental threats is starting to come to attention and perceive as a common threat by countries in the world, individuals, and nongovernmental organizations (NGOs). Ecological damage also considers causing widespread conflicts such as war, terrorism, or diplomatic trade disputes. Some experts think that climate change is causing instability and then causing the war. Most of those affected by climate change is detrimental to developing countries. Conflicts often occur with disputes with other countries, tribal clashes, population conflicts and riots (Perwita \& Yani, 2017: 130-131)

It based merely on exposure to national security, which means no threat from other countries as well as from non-countries and the environment. The security that experiences an expansion of meaning makes the environment an effort that must be maintained by the state for survival stability. Environmental degradation that occurs threatens the fulfillment of human survival needs. If it cannot meet, it will cause conflict or even threaten other national securities, be it political, economic, socio-cultural aspects.

Environmental security is used in this study to see the threat of climate change and ecological degradation that has an impact on the national security of the United States. United States national security to ensure the fulfillment of its domestic needs and a sense of security for its citizens, for example, threats from climate migrants, or rising sea levels. The exit of the United States from the 2015 Paris Agreement threatened environmental security and, at the same time, jeopardized national security.

\section{Research Method}

This study uses qualitative non-numerical research methods and emphasizes data collection and analysis. Qualitative research often relies on conclusions that are inductive (Boejoe, 2009: 15). Qualitative research methods have several types, one of which is descriptive-interpretation type; the writer uses the technique, namely data and phenomena that are obtained and then interpreted and concluded by the author to answer the research problem (Lamont, 2005: 30). Qualitative research chose to see the purpose of this study to understand the phenomenon of the effects of climate change and the exit of the United States from the 2015 Paris Agreement affecting national security. That is the data collection technique with primary data sources.

Primary sources were obtained from the United States Embassy of Indonesia for Indonesia and in the form of official website documents of the Obama Whitehouse archives when governing. Materials in the form of the United Nations Framework Convention on Climate Change (UNFCCC) reports and United States Department of Defense documents. Secondary data researchers obtained from collecting documents 
and data archives in the form of articles, magazines, websites, government publications, as well as relevant prior research.

\section{Result and Discussion}

\subsection{Climate Change as a Security Threat}

The concept of security has expanded the meaning of not only the state also the environment so that non-traditional security is categorized. Environmental damage can lead to conflict, disputes, civil disputes, and riots (Perwita \& Yani, 2017: 130). It was considering the definition of security, the state's physical protection conditions from external threats, both in the form of environmental risks.

Buzan also said that security is related to survival. Something that threatens the continuation of a unit, whether it is a particular collective or a principle that own, will be seen as a threat. So Buzan divides security into five dimensions, including the environment (Perwita \& Yani, 2017: 130).

United Nations Framework Convention on Climate Change (UNFCCC) Article 1, part 2 of the 1992 UNFCCC, defines climate change, which means a change of climate which attributes directly or indirectly to human activity that alters the composition of the global atmosphere of your atmosphere. Which also to natural climate variability observed over comparable periods (Wijoyo, 2012: 16). The cause of climate change is its industrialization activities releasing greenhouse gases, which consequently increases the earth's temperature so that climate change occurs (Winarno, 2014: 135). Another problem is the use of Cloro Floro Carbon (CFC) found in A.C., which is local but can cause the ozone layer to thin out and even be hollow in Antarctica and Africa. The use of CFC, which is locally and feels small, actually causes an influence on the global environment (Attfield, 2010: 21).

The impact of climate change can have implications for various sectors, ranging from drought and floods that cause crop failure or other disasters. Pollution can interfere with breathing, disease outbreaks, and decreased world food availability (Senthilingam 2016). Climate change has an impact on world food availability due to prolonged drought and the intensity of rain that has failed to harvest. Harvest failure caused hunger (DW.Com, 2016).

The threat of climate change, which can damage the environment and security threats, creates a conflict of power between countries regionally and globally that can affect instability (Perwita \& Yani, 2017: 130). The danger was as stated by the New Zealand Government, which released a statement on defense policy that indicated climate change as the most significant national security threat. New Zealand's concern because the Pacific region, which is geostrategically vulnerable to the effects of climate change, has become a struggle for many, especially the strengthening of China's influence. The Pacific region, which is susceptible to the impact of climate change, makes countries want to work together to tackle climate change, including China. Climate change sees as a trigger for China to increase its influence in the South Pacific and can damage regional stability. China, as one of the donors of climate change prevention efforts. Samoa's Prime Minister, Tuilaepa Aiono Sailele Malielegaoi, in November commented that Australia and America must do and follow China's lead in 
the Pacific region in preventing climate change. The New Zealand Government is concerned about regional instability, and therefore climate change is a threat to national security (Coverage 6 2018).

According to the National Climate Assessment report in 2018, climate change has exacerbated civil unrest, war, and sent migrants out of their countries. About 13 million Americans are estimated to be able to migrate from their homes because it expects to cause a sea-level rise of 6 feet by 2100. In 2013 in the Philippines when Typhoon Haiyan pushed 4 million people out of their homes six months later, more than 200 thousand of them still live in temporary shelters. Houston in August 2017, Hurricane Harvey flooded and turned off the electricity for hundreds of thousands of Teas residents. Around 32,000 people forced into housing. Whereas in Sub-Saharan Africa, climate change thought to be the most bird attacking the poorest parts of the world. Researchers expect long-term drought and extreme heat to trigger global mass migration from Sub-Saharan Africa to the North in the coming decades (Political Spy 2018).

Threats to security are no longer synonymous with state security, but also human security, including environmental protection. Climate change has a negative impact. A report from the medical journal The Lancet, states that the earth's temperature below 2 degrees Celsius cannot cause climate change, which impacts on children's health including infectious diseases, air pollution, and malnutrition. Air pollution from fossil fuels and climate change that occur threatens the health of children starting from the womb. Dr. Mona Sarfaty, director of the climate and health program at the George Mason University Climate Change Communication Center who was involved in the report, said: "their hearts beat faster than adults and their breathing speed was higher than adults." Also, children who breathe clean air will affect lung function better (The New York Times, 2019).

Environmental degradation that occurs is undoubtedly a security threat to living things in it, including individuals. The form of the danger of climate change as already explained. In essence, environmental degradation and scarcity of natural resources will trigger insecurity for the country and individuals. Climate change that occurs will also cause instability in the region.

\subsection{The Paris Agreement 2015 on the national security of the United States}

Industrial activities and exploitation of the environment that causes the temperature of the earth to rise and cause climate change have an impact on the lives of individuals and countries. The effect caused to various countries, a state can no longer assume that environmental problems are only internal problems, but all countries must work together to create ecological security (Bakry, 2017: 278). America As one of the global emitters has a responsibility to tackle climate change, and the following countries are contributors to global emissions: 
Figure 1. Comparison of Developed and Developing Countries in Achieving the 2015 Target for Reducing Carbon Emissions

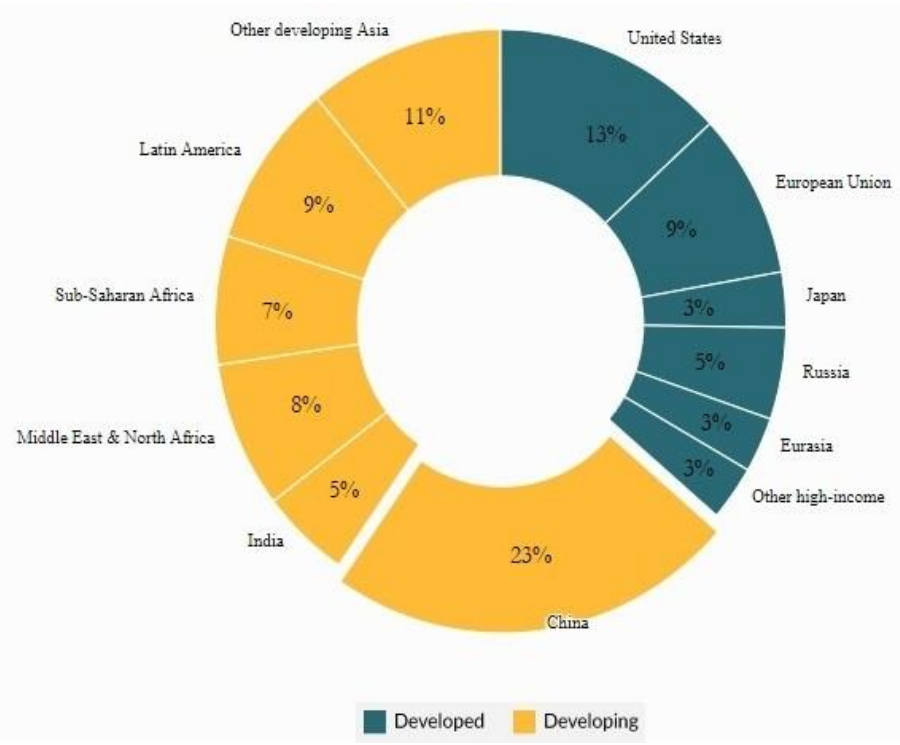

Source: Center for Global Development 2015.

Developed and developing countries in graph 1 explain the carbon emissions produced by these countries in the last year to 2015. The country is contributing to the world's most substantial carbon emissions in China, and the second position in the United States by 13\%. (Center for Global Development 2015).

Paris Agreement 2015 is one of the possible solutions in the framework of dealing with climate change. Compared to the Kyoto Protocol, the Paris Agreement 2015 reflects broader participation and guarantees developed countries to remain committed to reducing their emissions by 2030 to maintain the earth's temperature below 2 degrees celsius. Following the principles of the United Nations Framework Convention on Climate Change in 1992, which applies to all, and the aim of the 1992 UNFCCC is to stabilize greenhouse gases to maintain the global climate system so as not to endanger. Draft Agreement compile by Ad Hoc Working Group on Durban Platform for Enhanced Action, namely the Paris Agreement 2015, has been successfully adopted by more than 156 countries. The success of this adoption is essential to follow up on the principle of applicability for all, compared to the Kyoto Protocol (Pramudianto 2016, 84).

The attitude of the United States at COP 21 in Paris sees when President Obama proposed a 26-28 percent commitment to reduce carbon emissions from 2005 to 2025 (Earth Institute 2015). Proof of his commitment to the United States President Obama along with China to take foreign policy to ratify the Paris Agreement 2015. The attitude of the United States to deal with climate change convey by Obama by stating:

"...One of the reasons I ran for this office was to make sure that America does its part to protect this planet for future generations. Over the past seven and a half years, we've transformed the United States into a global leader in the fight against climate change. But this is not a fight that any one country, no matter how powerful, can take alone. That's why last December's Paris Agreement 2015 was 
so important. Nearly 200 nations came together as - a strong, enduring framework

to set the world on a course to a low-carbon future..." (The White House 2016).

In contrast to his successor, President Donald J. Trump, he declared to withdraw from the Paris Agreement, which had to ratify. The United States, as a global emitter in the official agreement of President Trump, announced that he would leave Paris Agreement 2015 on June 1, 2017, which officially carry out November 5, 2019, delivered by State Secretary Mike Pompeo (The Washington Post 2019). The reason is to burden the economy of his country, and Trump thinks the United States has made efforts to reduce carbon emissions following the economic growth of the United States. $74 \%$ between 1970-2018. Reduction of $13 \%$ of greenhouse gas emissions from 20052017, this happens along with the United States economy continues to grow, so he assumed no need to accept the Paris agreement (The Secretary of State 2019).

Trump received support from within his country to get out of Paris. The 2015 agreement obtained from the United States Congress of the Republican Party. The reason Parati Republik will accelerate economic growth. Also, partners campaigned for Trump to get donors from Baron Coal from Robert Murray, thus helping the coal industry to develop because during the 2015 Paris Agreement, increasing bankruptcy (2019 Foreign Policy).

Trump release the United States national security strategy, and prioritized, "The first task of our government is for its people, for its citizens - to fulfill their needs, to guarantee their security, defend their rights, and seek the values of their needs." President Donald J. Trump (United States Embassy and Consulate in Indonesia 2017) In the notes of the New National Security Strategy (NSS) eliminates the threat of a list of global change threats in national security strategies (Coverage 6 2017)

The disappearance of the threat of climate change as a threat to the national security of the United States indirectly threatens its national security. Given the security threats can be categorized as traditional and non-traditional. Trump does not understand the existence of non-traditional threats because of the origin of risks, core values, and those responsible are climate change is a threat to national security. Considering that national security is not only synonymous with the state and aggressive, but environmental integrity is one of the security threats.

As for the forms of climate change threats, the United States Department of Defense released that climate change is a threat to the national security of the United States. Based on reports from the United States Department of Defense, climate change can have an impact on health, food availability, requests, and coastal areas. Health threats from climate change can range from malaria, jaundice to malnutrition. Threats to food availability from climate change result in disruption of agricultural productivity, which in turn leads to starvation. Climate change also impacts refugees on the availability of food and water supply, which is the cause of regional, international, and domestic migration and conflict. Coastal areas that are not separated are also affected due to rising sea levels, which will cause coastal areas to disappear (Defense Science Board 2011).

Climate change is declared a national threat supported by military and intelligence leaders, Samuel J. Locklear III, Commander of the U.S. Navy Pacific 
Command stated: "Significant upheaval related to the Global warming" is probably the most likely thing that is going to happen ... that will cripple the safety of the environment, probably more than the other scenarios we all often talk about." the warming up of the planet will cripple environmental security. It will probably be worse than predicted.

Meanwhile, Former Army Chief of Staff General Gordon Sullivan stated: "Climate change is a national security issue. We found that climate instability will lead to instability in geopolitics and the impact of American Military operations around the world. "The army staff stated that climate change is a national security issue which could disrupt the stability of geopolitics and would have an impact on U.S. military operations that need to interfere in it. Tom Ridge, a former Assistant to the President of Homeland Security and Secretary during President George W. Bush, stated: "The U.S. national security community, including leaders from the military, homeland security, and intelligence, understand that climate change is a national security threat ... They're not talking about whether or not it is happening - it is... They're talking about addressing the problem and protecting the American people. It's time Washington does the same. "Ridge stated that climate change agreed by the army and intelligence services was an issue that threatened national security (Climate Nexus 2015). Change threatens regional stability. The threat of climate change in the Arctic region will influence the leadership of the United States in the region. A recent hearing on "Adding Opportunities, Challenges, and Threats to the North Pole" at the U.S. Senate Committee's Security Subcommittee on Trade, Science, and Transportation sought to highlight the needs of its United States leadership at the North Pole, by seeing climate change as a threat national security with an emphasis on the strategic role of the U.S. Coast Guard.

As an illustration of the threat of regional instability in January 2018, China declared itself a "North Pole state," and expressed its intention to build the "Polar Silk Road" from Shanghai to Hamburg. In 2017, China had three ice picks, one under construction, and a planned nuclear ice breaker. The development of Chinese domestic Arctic shipbuilding capabilities is significant. Russian President Vladimir Putin has stated that he sees the North Sea Route as "the key to the development of Russia's Arctic and regions in the East. Russia has also launched the first weapons icebreaker, which expects to commission in the next few years. Moreover, Russia has to mobilize increasingly aggressive behavior towards allies and partners in the northern United States (The Center for Climate and Security 2020).

U.S. military and intelligence officials identify climate change as a security crisis. The Congress reaffirmed with the 2018 Defense Minority Act that climate change is a direct threat to the national security of the United States. National Intelligence Director James Clapper cites climate change as a driver of unexpected instability (Natural Resources Council of Maine 2018). China and Russia in the Arctic region affect regional instability, which triggers them in the area is climate change. Therefore, there is a need for strong state leadership to maintain regional stability. The exit of the United States contradicts the priorities of Trump's security strategy, which states the influence of the United States leadership in the world (U.S. Embassy and Consulate in Indonesia, 2017). 
In 2017 the Western United States was affected by wildfires caused by extreme weather. Based on the National Interagency Fire Center (NIFC) report during 2017, there were more 71,499 forest fires, compared to 2016 with 65,575 forest fires. Especially in 2017, on September 2, due to scorching weather, there are several forest fires seen along the West Mountain and along the West Coast. Based on the NIFC report on September 6, 2017, 65 lights are taking place throughout the United States, all of which located in Western America. Fires on the Columbia River Gorge in Oregon spread smoke from the Pacific Northwest with cities such as Seattle and Portland. In Montana, 23 fires have burnt 400 thousand hectares, the largest being the Rice Ridge Fire that burned more than 100,000 hectares. Dry summers and extreme heat throughout the western United States are the reason for fires (Science \& Information for a ClimateSmart Nation 2017).

The non-state nature of threats, and the responsibilities of the state, and core values are dimensions of environmental risks with the exit of the United States from the Paris Agreement 2015 globally slowing down global carbon emissions. The impact causes global warming and rising temperatures. Globally, the United States, as the second global emitter, will slow down efforts to reduce emissions below 2 degrees celsius. As a result, the earth's temperature will continue to decline and have an impact on the environmental crisis. The implications for climate funding will also affect because the United States is the leading supporter of \$ 6.44 million per year or 20 percent of UNFCCC operations. Thus the Paris Agreement's operational budget can be disrupted. And the operationalization of the Intergovernmental Panel on Climate Change (IPCC) in conducting climate change studies can also influence (IESR 2017).

The threat of climate change to the United States will lose the equivalent of eight million Grand Canyon national parks or 24 million hectares naturally between 2001 and 2017 due to agricultural energy development, housing expansion, and other human factors. This condition enables the United States to be vulnerable to the effects of climate change. A study from Center American Progress entitled "How Much Nature Must Defend by America" reports strives to calculate land loss, which threatens the security of the United States from the worst effects of climate change and wildlife extinction (Coil 2019).

The United States Armed Forces states that climate change is a double threat "multiple threats" that can threaten various sectors such as health, food availability, rising water, and political resilience. In the political area, countries that have weak political institutions will find it difficult to cope with drought, floods, and other natural disasters. Many who are affected by climate change are partners from the United States, namely the Middle East, Africa, and other regions. Vulnerable political resilience will cause social and political instability, ultimately endangering U.S. energy imports and other interests. Hunger caused by declining agricultural production will increase the risk of conflict, so the United States Armed Forces need to intervene to help the country, and that can cost the United States billions of dollars every year. Hunger caused by declining agricultural production will increase the risk of conflict so that the United States Armed Forces need to intervene to help the country, and this can cost the United States billions of dollars each year (Scripps Institution of Oceanography 2005). 
National security threats as a result of climate change have an impact on U.S. military bases located in coastal areas due to sea-level rise and storm surges. The National Intelligence Council has identified United States installations that face a high risk of rising sea levels. The world's base, the Norfolk Naval Sation in Virginia which experiences tidal floods, with almost every day. When sea levels rise, several military facilities, including the Portsmouth Navy Shipyard and the Bath Iron Works, are calculated to have a high budgetary impact due to floods and storms. Rising costs place a burden on military personnel due to extreme weather, the charge of military personnel responsible for handling humanitarian crises and natural disasters, for example, the Pentagon, which mobilized 24,000 personnel for emergency response, disaster relief, and rebuilding efforts. Cost increases expect to increase as a result of climate change (Natural Resources Council of Maine, 2018).

Sea level rises, and hurricanes have caused billions of dollars in economic damage. Storms can threaten coastal populations and infrastructure. From 2000-2009, the federal government spent $\$ 288.9$ billion in assistance in handling hurricanes, up from $\$ 84.4$ billion in the 1990s. Hurricane Sandy in 2012 killed 117 Americans and caused a $\$ 70$ billion economy, and Hurricane Katrina killed 1,5,000 American fatalities in 2005, causing damage to a total of $\$ 135$ billion. Climate change due to global warming caused by humans resulted in the melt of global ice sheets. That eventually increased sea level and will be even worse with the release of the United States from the Paris Agreement 2015 because efforts to reduce the earth's temperature are impossible to achieve (American Security Project, 2013).

The higher risk is the presence of large-scale refugees due to climate change. The scarcity of natural resources and disasters caused by climate change forces individuals to migrate to other countries that can meet their needs. International Organization of Migration proposes three classifications of climate refugees. That is emergency migrants (people temporarily displaced due to sudden natural disasters), displaced people (people who currently affected by long-term impacts), and motivated migrants (People who try to avoid future environmental hazards). Conflicts will occur as a result of refugees who come, for example, primordial issues. Examples of the adverse effects of climate migration see as the best known is the conflict that existed in Dafur in Sudan in 2003. the battle is associated with the struggle for scarce resources, Syria's drought from 2006 to 2010 considers as one of the triggers that led to migration, civil unrest, and finally armed conflict (Environmental and Energy Study Institute 2017).

\section{Conclusion}

The author concludes that with the departure of the United States from the 2015 Paris Agreement, it has the consequences of threatening its national security. National security is, by definition, the absence of threats from other countries or from other aspects that disturb security. There is a contradiction in Trump's national security strategy that seeks to protect its citizens from any threat. Still, the United States came out of the Paris Agreement 2015, thus indirectly threatening national security because the Paris Agreement is an effort to protect the environment and each individual from the threat of global warming and change for all countries, including the United States. Thus 
the United States of America should be present to guarantee its national security from various threats, including the negative impacts of climate change. The United States should not come out of the Paris Agreement 2015. 


\section{BIBLIOGRAPHY}

\section{Books}

Anak Agung Banyu Perwita \& Yanyan Mochamad Yani. 2017. Pengantar Ilmu Hubungan Internasional. Kelima. Bandung: Remaja Rosdakarya.

Attfield, Robin. 2010. Etika Lingkungan Global. Edited by Widodo. Pertama. Bandung: Kreasi Wacana.

Bakry, Umar Suryadi. 2017. Dasar-Dasar Hubungan Internasional. Pertama. Depok: Kencana.

Boejoe, H. R., 2009. Analysis in Qualitative Research. First. London: SAGE.

Darmono, Bambang, Wijoko, TSL Toruan, and Joko Suharsoyo. 2010. Keamanan Nasional Sebuah Konsep Dan Sistem Keamanan Bagi Bangsa Indonesia. Dewan Keamanan Nasional. Jakarat: Sekertaris Jenderal Dewan Ketahanan Nasional.

Lamont, Christoper. 2005. Research Methods in International Relations. First. London: SAGE.

Perwita, Anak Agung Bayu. 2008. "Dinamika Keamanan Dalam Hubungan Internasional Dan Implikasinya Bagi Indonesia.” Universitas Parahyangan.

Rachmat, Angga Nurdin. 2015. Keamanan Global Transformasi Isu Keamanan Pasca Perang Dingin. Edited by Sutejo Atmowasito. Kesatu. Bandung: Alfabeta.

Winarno, Budi. 2014. Dinamika Isu-Isu Global Kontemporer. Edited by Tri Admojo. Pertama. Yogyakarta: CAPS (Center of Academic Publishing Service).

\section{Journals}

Chai, Qimin, Sha Fu, Huaqing Xu, Weiran Li, and Yan Zhong. 2017. "The Gap Report of Global Climate Change Mitigation, Finance, and Governance after the United States Declared Its Withdrawal from the Paris Agreement." Chinese Journal of Population Resources and Environment 15 (3): 196-208. https://doi.org/10.1080/10042857.2017.1365450.

Pramudianto, Andreas. 2016. "Dari Kyoto Protocol 1997 Ke Paris Agreement 2015 : Dinamika Diplomasi Perubahan Iklim Global Dan Asean Menuju 2020.” Global: Jurnal Politik Internasional 18 (1): 76. https://doi.org/10.7454/global.v18i1.119.

Rhodes, Christopher J., 2017. "U.S. Withdrawal from the COP21 Paris Climate Change Agreement, and Its Possible Implications." Science Progress 100 (4): 411-19. https://doi.org/10.3184/003685017X15063357842600.

Saad, Aaron. 2018. "Pathways of Harm: The Consequences of Trump's Withdrawal from the Paris Climate Agreement." Environmental Justice 11 (1): 47-51. https://doi.org/10.1089/env.2017.0033.

Wijoyo, Oleh Suparto. 2012. "Dinamika Komitmen Internasional Dalam Kerangka Pengendalian Global Warming." Kanun: Jurnal Ilmu Hukum 14 (1): 13-35. https://doi.org/10.24815/kanun.v14i1.6197.

Zhang, Hai Bin, Han Cheng Dai, Hua Xia Lai, and Wen Tao Wang. 2017. "U.S. Withdrawal from the Paris Agreement: Reasons, Impacts, and China's Response." Advances in Climate Change Research 8 (4): 220-25. https://doi.org/10.1016/j.accre.2017.09.002.

\section{Reports}


Defense Science Board. 2011. "Trends and Implications of Climate Change for National And." Defense Science Board.

Natural Resources Council of Maine. 2018. "Climate Change Impacts on National Security." Natural Resources Council of Maine. 2018.

Scripps Institution of Oceanography. 2005. "CLIMATE CHANGE: Multiplying Threats to National Security." San Diego. https://scripps.ucsd.edu/centers/cmbc/wpcontent/uploads/sites/39/2015/10/Climate-Change-and-National-Security5-12012.pdf.

WALHI. 2015. "Tinjauan Lingkungan Hidup 2015: Menagih Janji Menuntut Perubahan," 1-48. http://www.walhi.or.id/2016/12/22/outlook-2015-menagihjanji-penuntut-perubahan/.

\section{Press Release}

The Secretary of State. 2019. "On the U.S. Withdrawal from the Paris Agreement." U.S. Department of State. 2019. https://www.state.gov/on-the-u-s-withdrawal-from-theparis-agreement/.

The White House. 2016. "President Obama: The United States Formally Enters the Paris Agreement." The White House. 2016.

https://obamawhitehouse.archives.gov/blog/2016/09/03/president-obama-unitedstates-formally-enters-paris-agreement.

United Nations Security Council. 2007. "Security Council Holds First-Ever Debate On Impact Of Climate Change On Peace, Security, Hearing Over 50 Speakers." United Nations Security Council. 2007. https://www.un.org/press/en/2007/sc9000.doc.htm.

Kedutaan Besar Amerika Serikat dan Konsulat di Indonesia. 2017. "Presiden Donald J. Trump Mengumumkan Strategi Keamanan Nasional Untuk Memajukan Kepentingan Amerika.” Kedutaan Besar Amerika Serikat Dan Konsulat Di Indonesia. 2017. https://id.usembassy.gov/id/presiden-donald-j-trumpmengumumkan-strategi-keamanan-nasional-untuk-memajukan-kepentinganamerika/ (17/01/2020).

\section{Website}

American Security Project. 2013. "FACT SHEET: Climate Change's Threats to the United States - Lessons from the Netherlands." America Security Project. 2013. https://www.americansecurityproject.org/climate-changes-threats-to-the-unitedstates-lessons-from-the-netherlands/. (17/01/2020).

BBC News. 2017. “Amerika Serikat Mundur Dari Kesepakatan Iklim Paris 2015.” BBC News. 2017. https://www.bbc.com/indonesia/dunia-40126676. (15/01/2020).

Center for Global Development. 2015. "Developing Countries Are Responsible for 63 Percent of Current Carbon Emissions." Center for Global Development. 2015./ https://www.cgdev.org/media/developing-countries-are-responsible-63-percentcurrent-carbon-emissions. (17/01/2020)

Climate Nexus. 2015. "National Security Risks." Climate Nexus. 2015. https://climatenexus.org/climate-change-us/politics-and-policy/national-scecurity- 
risks/. (17/01/2020)

CNN Indonesia. 2015a. "BMKG: El Nino Itu Bukan Gelombang Panas." CNN

Indonesia. 2015. https://www.cnnindonesia.com/internasional/20151130171044-

137-94992/sepuluh-negara-penghasil-emisi-karbon-dioksida-terbesar?

$(15 / 01 / 2020)$

_. 2015b. "Sepuluh Negara Penghasil Emisi Karbon Dioksida Terbesar." CNN Indonesia. 2015. https://www.cnnindonesia.com/internasional/20151130171044137-94992/sepuluh-negara-penghasil-emisi-karbon-dioksida-terbesar? $(15 / 01 / 2020)$

—. 2017. "Kadar Karbon Dioksida Di Atmosfer Capai Level Tertinggi." CNN Indonesia. 2017. https://www.cnnindonesia.com/gaya-hidup/20171031142925255-252425/kadar-karbon-dioksida-di-atmosfer-capai-level-tertinggi. $(15 / 01 / 2020)$.

DW.Com. 2016. "Perubahan Iklim Picu Kelaparan.” DW.Com. 2016. https://www.dw.com/id/perubahan-iklim-picu-kelaparan/av-18980926. $(16 / 01 / 2020)$

Earth Institute. 2015. "What Is the U.S. Commitment in Paris?" Earth Institute. 2015. https://blogs.ei.columbia.edu/2015/12/11/what-is-the-u-s-commitment-in-paris/. $(17 / 01 / 2020)$

Environmental and Energy Study Institute. 2017. "Issue Brief: The National Security Impacts of Climate Change." Environmental and Energy Study Institute. 2017. https://www.eesi.org/papers/view/issue-brief-the-national-security-impacts-ofclimate-change. (17/01/2020)

Foreign Policy. 2019. "Is the United States Leaving the Paris Climate Agreement?" Foreign Policy. 2019. https://foreignpolicy.com/2019/11/05/paris-climateagreement-united-states-withdraw/. (17/01/2020).

IESR. 2017. "Implikasi Keluarnya Amerika Serikat Dari Paris Agreement Terhadap Agenda Perubahan Iklim Global.” IESR. 2017. http://iesr.or.id/implikasikeluarnya-amerika-serikat-dari-paris-agreement-terhadap-agenda-perubahan-iklimglobal-bagian-2-2/. (15/01/2020)

Kompas Internasional. 2018. "Bank Dunia: Perubahan Iklim Dorong 140 Juta Orang Bermigrasi Pada 2050." Kompas. 2018. https://internasional.kompas.com/read/2018/03/20/10514091/bank-duniaperubahan-iklim-dorong-140-juta-orang-bermigrasi-pada-2050. (15/01/2020)

Kumparan. 2019. "9 Juta Hektare Lahan Alamnya Hilang, AS Semakin Rentan Terdampak Perubahan Iklim.” Kumparan. 2019. https://kumparan.com/trubus-id/9juta-hektare-lahan-alamnya-hilang-as-semakin-rentan-terdampak-perubahan-iklim1rdoBhtLSWi. (17/01/2020)

Liputan 6. 2017. "Trump Coret Perubahan Iklim Dari Daftar Ancaman Nasional AS." Liputan 6. 2017. https://www.liputan6.com/global/read/3200550/trump-coretperubahan-iklim-dari-daftar-ancaman-nasional-as. (17/01/2020).

- 2018. "Perubahan Iklim Jadi Risiko Keamanan Nasional Terbesar Di Selandia Baru." Liputan 6. 2018. https://www.liputan6.com/global/read/3800755/perubahan-iklim-jadi-risikokeamanan-nasional-terbesar-di-selandia-baru. (16/01/2020)

Mata Mata Politik. 2018. "Perubahan Iklim Bisa Paksa Migrasi 13 Juta Penduduk Amerika.” Mata Politik. 2018. https://www.matamatapolitik.com/perubahan-iklimbisa-paksa-migrasi-13-juta-penduduk-amerika/. (16/01/2020) 
Natural Resources Council of Maine. 2018. "Climate Change Impacts on National Security." Natural Resources Council of Maine. 2018.

https://www.nrcm.org/programs/federal/federal-climate-and-energy-issues/climatechange-impacts-on-national-security/ (17/01/2020).

PBS News. 2015. "President Calls Climate Change the 'Greatest Threat to Future Generations' in State of the Union." PBS News. 2015. https://www.pbs.org/newshour/science/president-calls-climate-change-greatestthreat-future-generations-state-union. (15/01/2020)

Reuters. 2016. "U.S., China Ratify Paris Climate Agreement." Reuters. 2016. https://www.reuters.com/article/us-china-climatechange-idUSKCN11901W. $(15 / 01 / 2020)$.

Science \& Information for a Climate-Smart Nation. 2017. "Massive Fires Burning across the West in September 2017." Climate.Gov. 2017.

https://www.climate.gov/news-features/event-tracker/massive-fires-burningacross-west-september-2017. (17/01/2020)

Senthilingam, Meera. 2016. "How Climate Change Is Affecting Your Health." London School of Hygiene \& Tropical Medicine. 2016. https://www.lshtm.ac.uk/research/research-action/features/how-climate-changeaffecting-your-health. (15/01/2020)

The Center for Climate and Security. 2020. "America Must Reassert Its Leadership In The Arctic For 21st Century Security." The Center for Climate and Security. 2020. https://climateandsecurity.org/2020/01/15/america-must-reassert-its-leadership-inthe-arctic-for-21st-century-security/\#more-18894. (17/01/2020).

The New York Times. 2019. "Climate Change Poses Threats to Children's Health Worldwide." The New York Times. 2019. (16/01/2020)

The Washington Post. 2019. "Trump Makes It Official: U.S. Will Withdraw from the Paris Climate Accord." The Washington Post. 2019. https://www.washingtonpost.com/climate-environment/2019/11/04/trump-makesit-official-us-will-withdraw-paris-climate-accord/. (17/01/2020)

Wuebbles, D., D. W. Fahey, and K. A. Hibbard. 2017. "How Will Climate Change Affect the United States in the Decades to Come?" EOS. 2017. https://doi.org/https://doi.org/10.1029/2017EO086015. (17/01/2020). 